UDC: 811.111'243; 811.111'27:004.738.5

\title{
THE PRAGMALINGUISTIC AND SOCIOPRAGMATIC ASPECTS OF ENGLISH: APPLYING ANALYTIC ABILITIES TO FOREIGN LANGUAGE TEACHING
}

\author{
SENKA MAJETIĆ 1 \\ University of Bihać, \\ Department of English Language and Literature, \\ Bosnia and Herzegovina
}

Ovaj rad predstavlja rezultate istraživanja upotrebe pragmatike u korpusu elektronskih poruka studenata koji nisu izvorni govornici engleskog jezika s posebnim osvrtom na zahtjeve. Inicijalni podaci iz studije pokazuju da se neizvorni govornici razlikuju od izvornih govornika engleskog jezika u razini prihvatljivosti (tj. utiska koji pisani sadržaj ostavlja na primatelja) zahtjeva izraženih elektronskim porukama. Podaci, također, pokazuju da se neizvorni govornici razlikuju od izvornih govornika u specifičnim strategijama povezanim sa strukturom i sadržajem upotrjebljenim u njihovim zahtjevima. Dodatni podaci iz ove studije pokazuju da eksplicitne upute mogu pozitivno utjecati na utisak u zahtjevima neizvornih govornika i na dugoročnu upotrebu pragmatike, iako je najveći efekt uočen u odgovarajućoj primjeni engleskih struktura. Rezultati ove studije ukazuju na potrebu za poučavanjem neizvornih govornika engleskog jezika pragmatici koja se koristi u elektronskim porukama i otvaranje mogućnosti pozitivnih rezultata ovog poučavanja.

Ključne riječi: elektronska poruka, neizvorni govornici, pragmatika, zahtjev.

\section{INTRODUCTION}

Over the past decade, researchers have become increasingly interested in examining the usage of e-mail by second language learners. Early studies looked at the effective use of e-mail in instructional settings (Warschauer 1995; St. John and Cash 1995). Additional studies addressed the use of e-mail institutional settings, such as business (Inglis 1998; Gains 1999) and academia (Gains 1999; Lan 2000).

1 Kontakt podaci (Email): majetic.senka@yahoo.com 
More recently, researchers have directed their attention to the pragmatics of e-mail messages (Hartford and Bardovi-Harlig 1996; Weasnforth and Biesenbach-Lucas 2000; Chen 2001), although no attention to date has been paid to the instruction of e-mail pragmatics.

This study hopes to contribute to the body of research by reporting the results of a study that examined the pragmatics of e-mail requests made by non-native speakers (NNSs) of English in an instructional setting. In the ensuing paper, I begin by providing a review of the literature most relevant to the current study. Afterwards, I describe the research methodology used during the project, including the participants, the study design, and data coding. Finally, I present and discuss some of the data gathered over the course of the research period, focusing on pragmatic differences between NNSs and native speakers (NSs) of English, and the effects of instructing NNSs on the correct usage of pragmatics in English.

\subsection{PRAGMATIC DEVELOPMENT AND ESL}

Numerous language researchers have looked into the development of pragmatics in a second language, particularly in English. A consistent theme across the various studies related to pragmatic development and ESL is that pragmatics can and should be learnt: pragmatics should be learnt because it does not appear to be easily transferable from first language (L1) to second language (L2) (Kasper 1992); pragmatics should be learnt because this will raise awareness of appropriate language use, which has been shown to aid in language development (Schmidt 1993); and pragmatics can be learnt, as is evidenced by a number of studies of classroom language learning and instruction. Bardovi-Harlig (2001) reached the same conclusions in her extensive review of the empirical evidence from research of L2 pragmatic production, judgment, perception, competence, and proficiency. This theme is essential to the overall conceptualization of my study and constitutes the theoretical foundation of this line of research.

Motivated by the initial research that examined interlanguage development, many in the field of interlanguage pragmatics (ILP) have applied the theories proposed by the previous SLA research to the instruction of pragmatics in the classroom setting. Several studies have focused on developing awareness of pragmatics through explicit instruction. Their results generally support the notion that pragmatic development can be enhanced through explicit awareness-raising technique. Many other studies have compared implicit and explicit instruction of pragmatics in the ESL setting. Takahashi (2001), Tateyama (2001), and Yoshimi (2001) each found explicit instruction of pragmatic features to have a greater effect on pragmatic competence than implicit instruction. In consideration of such positive findings from previous research, it appears that explicit instruction does in fact assist pragmatic development in second language learners. This conclusion provides further motivation and rationale for my study. 


\subsection{REQUESTS AND ESL}

One of the most frequently occurring speech acts across cultures, and one of the most researched as well, is the request. Blum Kulka, House, and Kasper (1989) devoted a large portion of their edited volume to studying the pragmatics of the request speech act, through their research, they developed a process for designing appropriate data elicitation tests and created a detailed coding manual to assist in analyzing discourse data.

A number of researchers have investigated the performance of English requests by a specific cultural group: Kitao (1990) looked at Japanese learners of EFL, Trosborg (1995) studied Danish learners of EFL, Kim (1995) examined Korean learners of ESL. Each of these researchers found evidence of negative transfer of L1 pragmatics and concluded with the need for explicit instruction in making English requests. Kasange (1998) had the same findings in a study of ESL learners at an American university and found no evidence of negative L1 transfer of pragmatics with regards to the request speech act.

In quite a different approach to researching the pragmatic development of requesting in English, Li (2000) conducted an ethnographic case study of a female ESL learner in workplace environment in Canada and found that her pragmatic development came about mainly through language socialization with coworkers.

An interesting investigation by Schmidt (1994) compared actual request data gathered at service counters to request lessons found in four popular ESL textbooks. Schmidt's results showed that textbooks were deficient in the range of real-world request types and the explanations of request types given.

Additional work in this area of pragmatics research has focused on the instruction of requests. Rose (1999) provided a report of the successful instruction of requests to students in Hong Kong using pragmatic consciousness-raising (PCR) techniques. Rose defines PCR as

...an inductive approach to developing awareness of how language forms are used appropriately in context. The aim is not to teach explicitly the various means of... performing a given speech act... but, rather, to expose learners to the pragmatic aspects of language... and provide them with the analytical tools they need to arrive at their own generalizations concerning contextuality appropriate language use. (Rose 1999: 171)

With such a definition, Rose further explains that PCR is a process in which pragmatic awareness is raised first by introducing students to a particular pragmatic feature, then by activating students' $L 1$ knowledge of the pragmatic feature, and finally by analyzing English data for the same pragmatic feature. Through such a process, students will become aware of "both the pragmalinguistic and sociopragmatic aspects of English" as they develop "analytic abilities that they can apply to future language learning" (Rose 1999: 180). This approach to raising pragmatic awareness will influence the treatment design of my study. 


\subsection{E-MAIL PRAGMATICS}

With the development of the Internet, increased attention has been given to the use of pragmatics in computer-mediated communication (CMC). Since Shea (1994) first presented her principles of business "netiquette" (a bland of the words network and etiquette), which are basic rules and guidelines for behaving and interacting via CMC, several others (Hambridge 1995; Rinaldi 1998) have further developed and applied netiquette principles to the full range of possible CMC purposes, from formal (e.g., business e-mail, academic discussion boards) to informal (e.g., Internet "fun-club" chat rooms). At this point in time, netiquette guidelines have become conventionalized and are publicized wherever CMC may take place, from office settings to Internet cafés; they have even found their way into ESL textbooks (e.g., Swales and Feak 2000; Hacker 2003) and onto university writing web sites (e.g., Hughes 2002; Essid 2003).

The line of research most directly relevant to my study are the handful of reports that investigate the pragmatics of e-mail requests in ESL environment. Of particular interest to my study is the report by Hartford and Bardovi-Harlig (1996), who analyzed for perlocutionary effect e-mail requests sent by NS and NNS graduate students to professors. They concluded that, in general, NNS e-mails did not adequately address imposition, which negatively affected perlocution (i.e., the effect that an utterance has on its recipient). In addition, NNS messages contained fewer downgraders and other mitigating supportive moves such as grounders and apologies, which negatively affected the impact of the requests. Weasenforth and Biesenbach-Lucas (2000) analyzed variation between graduate NSs and NNSs employed pragmatic strategies that negatively affected the perlocution of their English e-mail requests. Chen (2001) analyzed and compared e-mail requests sent by Taiwanese and U.S. graduate students to their professors. She concluded that the Taiwanese and U.S. students used different request strategies than the U.S. students due to culturally different perceptions of power relations, familiarity, and imposition. This study illuminates the possibility of divergent culture-specific pragmatic strategies employed by even advanced-level ESL students when making e-mail requests in the academic setting.

\subsection{INSTRUCTION OF E-MAIL PRAGMATICS}

At this point in time, e-mail pragmatics in the ESL setting remains largely underresearched. While important groundwork has been done to investigate cross-cultural differences evident in e-mail pragmatics, the effects of instruction of e-mail pragmatics remain virtually untouched.

Consistent with the absence of research into the effect of instruction in e-mail pragmatics, there is also a shortage of pedagogical materials devoted to the systematic instruction of the pragmatics of e-mail communication in the ESL context. Various textbooks of academic writing for ESL students provide very brief sections on e-mail usage that focus primarily on formal and functional rules for the university setting. Probably the most comprehensive Internet site devoted to English writing, OWL at 
Purdue University (http://owl.english.purdue.edu), devotes minimal attention to e-mail pragmatics, and even then, it is targeted to NSs of English and provides no mention of miscommunications or violations that may arise due to cross-cultural differences in pragmatics (Hughes 2002). However, on the bright side, Ford (2003), Mach and Ridder (in press), and Weasenforth (2003) each have developed lessons and materials devoted to issues of e-mail pragmatics in the ESL environment, particularly in academia.

\subsection{RESEARCH QUESTIONS}

Drawing from the preceding literature review, the following research questions guided the current study:

- Is there a difference between the perlocution of NS and NNS English e-mail requests?

- What are the differences between the pragmatic features of NS and NNS English e-mail requests?

- What are the effects of instruction to NNSs in the usage of appropriate pragmatic features when making e-mail requests?

\section{MATERIAL AND METHOD}

\subsection{PARTICIPANTS}

Over the course of the 2011-2012 academic year, I completed a study in which I investigated the usage of e-mail pragmatics. I conducted this study in my own two sections, the advanced-level writing course for undergraduate $3^{\text {rd }}$ year ESL students at the University of Bihać. My particular section met three days per week in 45-minute class sessions. Qualitatively, there seemed to be no differences between the two sections: they were at the age of 21 , they both met during the morning, they both contained approximately the same numbers of students, and they both utilized the same textbook and instructional materials.

Over the two semesters, I gathered complete data sets from a total of 15 NNS. Data from an additional 10 students were incomplete, missing at least one message each, and were therefore excluded from this study. However, in the following analysis and discussion section, I do not consider cultural differences in pragmatic usage, for cultural differences do not seem relevant at this stage in my analysis of the effects of instruction.

At the beginning of each semester, these students indicated on a general course questionnaire that they frequently used computers and e-mail programs, and that they had never received any formal instruction in either computer or e-mail usage. Each of the students also supplied a valid e-mail address for the purposes of communication outside of classroom instruction time. 


\title{
2.2 RESEARCH DESIGN
}

Pre-test. The study relied on a quasi-experimental design that included a pre-test, treatment, immediate post-test design. The pre-test was administered during the third week of each semester. It consisted of the following task:

\begin{abstract}
Write me an e-mail message asking me to extend the due date for a paper that's due soon. Provide me an adequate reason, and convince me that I should grant your request. Give me any other information that I should grant your request. Give me any other information that you think would help me accept your excuse. Send your message to me the day before our next class.
\end{abstract}

My students were given this assignment in class and were told to complete the task before the next class meeting. They were provided with no additional instructions about the assignment.

When designing the prompt, I decided to have the students address a professor of a course under the assumption this may help the students become more personally connected to the prompt, which may result in a serious, well-thought-out message. Furthermore, I specified that the students should provide adequate reason and additional information, and use proper form and language because I wanted the students to understand that this was a real, serious assignment. The specification of the prompt was an attempt to ensure that the students would not submit a minimal message written a few minutes before the class, but instead would submit a message written after careful thought and planning, as would be the case in real life if they were writing a request to a real professor.

Treatment. The very next class session was held in a campus computer lab. The students were presented with a lecture based on rules of netiquette via web site with the goal of understanding how netiquette guidelines will help to make e-mail messages more acceptable and effective. After a brief introduction to netiquette principles, we talked about how these principles could be applied to different CMC situations, particularly the ones that the students could encounter in their academic careers. Next, the students examined some examples of poorly constructed e-mail messages and ways to improve them, while reflecting on the netiquette guidelines. In doing so, aspects of perlocution and politeness were discussed rather cursorily. Lastly, students viewed additional web sites on the Internet devoted to netiquette, specifically Shea's (1994) "Netiquette"page, Rinaldi's (1998) "The Net: User Guidelines and Netiqette" page. This was done to raise further awareness of e-mail pragmatics as an issue that extends far beyond the classroom and computer lab and applied to the entire Internet community. This lesson filled the full 45-minute class period and constituted the entire treatment.

Post-test. As their homework assignment due before the next class session, students were required to resubmit their previous e-mail requests based on what they had learned from the netiquette lesson. This comprised the immediate posttest portion of the study. During the remainder of each semester, no classroom time or otherwise was spent on issues related to e-mail pragmatics. The delayed post-test was administered during finals week, a full 15 weeks after treatment. The task of the 
delayed post-test was a very similar assignment used for the pre- and immediate posttest which was also administered as a homework assignment. The assignment differed from the previous prompt only in that it asked students to request an extension of due date of the final course paper. This change was made in an attempt to make the assignment more realistic, since the delayed post-test was administered during finals week, when the students were actually thinking about these matters in their lives.

Data coding. After data was gathered, I coded each e-mail message onto a separate coding form that I developed, based on Blum-Kulka, House, and Kasper (1989) and Shea (1994). Blum-Kulka, House, and Kasper (1989) provide an elaborate coding scheme developed for the Cross-Cultural Speech Act Realization Project (CCSARP) for analyzing requests. Following the CCSARP coding manual, analysis of requests includes three distinct stages: 1) identification of the head act, which is the minimum segment that constitutes the actual requests; 2 ) identification of non-essential elements that modify the head act internally; and 3) identification of non-essential elements relevant yet external to the head act. Together these parts contribute to a thorough analysis of a given request. For the purpose of my study, I combine the coding scheme of the CCSARP with required aspects of formal e-mail requests.

Additionally, the scope of the coding scheme was adjusted for the lengthier stream of discourse of the e-mail messages that were gathered by the task-based performance assessment in the current study instead of the single utterances gathered by discourse completion task (DCTs), for which the CCSARP was originally designed. Therefore, the coding form has separate sections for recording the tracking number of the e-mail message, the length of the message, the formal features of netiquette found in the message and the request(s) found in the message, and overall ratings for perlocutionary effect and politeness level of the message.

The rating for perlocutionary effect is based on a 5-point scale ranging from the least acceptable to the most acceptableconcerning the likelihood that the receiver would accept the request:

\section{Rating Perlocutionary Effect}

\section{Least Acceptable \\ 2 Less Acceptable \\ 3 Acceptable \\ 4 More Acceptable \\ 5 Most Acceptable}

This 5-point scale was chosen due to its ability to allow for comparisons and slight differences in ratings across messages, while at the same time allowing for manageable analysis. The scale requires making a holistic judgment about the acceptability of a message based on experience and pragmatic intuition. The factors affecting judgment include an adequately formed request, an appropriate level of politeness, and an adequate use of downgraders and positive supportive moves. At one end of the scale, a rating of "Least Acceptable" would indicate a high likelihood that the recipient of the message would not accept the request. At the center of the scale, a rating of "Acceptable" 
would indicate that the request in the message would probably be accepted by the recipient. At the other end of the scale, a rating of "Most Acceptable" would indicate a high likelihood that the recipient of the message would accept the request. As with the politeness rating scale, points 2 and 4 allow for slight differences in perlocutionary effect, depending on specific strategies employed in individual messages. The rating for politeness is based on a 5-point scale ranging from impolite to overly polite, and it concerns the level of overall formality perceived by the receiver:

\title{
Rating- Politeness Level
}

\author{
1 Very Impolite \\ 2 Slightly Impolite \\ 3 Polite \\ 4 Too Polite \\ 5 Overly Polite
}

This 5-point scale was chosen for the same reason as the perlocutionary effect rating scale discussed previously. At one end of the scale, "Very Impolite" messages would be the ones that are very brief and terse, demanding, insulting, or otherwise perceived as rude. At the other end of the scale, "Overly Polite" messages would be the ones that contain inappropriate uses of politeness markers, complements, or expressions of gratitude. At the center of the scale, "Polite" messages were those that follow netiquette guidelines by briefly stating a purpose, asking a request, providing only necessary details, and thanking the recipient, without discussing personal issues or qualities (Shea 1994; Rinaldi 1998). Points 2 and 4 allow for slight differences in politeness, depending on specific strategies employed in individual messages.

After collecting all of the study data, I coded and tarred each message, using the data coding form discussed previously. Additionally, $20 \%$ of the data, selected at random, was coded by a colleague from my same department, who was experienced with teaching students in the same course. This same colleague also rated $100 \%$ of the study data for perlocution and politeness. Regarding data coding, the reliability between the two was $73 \%$, which is rather low; however, considering that the coding form includes 43 separate categories, the data messages averaged 122 words in length, and colleague received very little training, this reliability is acceptable for my purposes in this study. Regarding data rating reliability, the results were much better, with $86 \%$ reliability for perlocution ratings and $89 \%$ reliability for politeness ratings. In the following data analysis, I focus on my coding and ratings of the data only.

\section{RESULTS AND DISCUSSION}

Throughout the course of the research project, I gathered a total of 74 e-mail requests for data analysis: 45 from the 15 NNSs in the form of pre-, immediate post-, and delayed post-tests, and 29 from the NSs as baseline data. Due to limited space, I will focus on my research questions. 
Is there a difference between the perlocution of NS and NNS English e-mail requests?

Across the data set, NSs were rated on average just slightly above "acceptable" for perlocution, while NNSs were rated a full point below NSs in the "unacceptable" range, on their pre-test e-mail messages. Table 1 below shows descriptive statistics of the e-mail perlocution ratings.

\begin{tabular}{lrrrrr}
\hline & N & M & SD & MIN & MAX \\
\hline NS & 29 & 3.14 & 0.74 & 2.00 & 4.00 \\
NNS & 15 & 2.20 & 0.68 & 1.00 & 3.00 \\
\hline
\end{tabular}

Table 1: Descriptive Statistics for Perlocution

This initial analysis shows that the NNSs tend to produce less acceptable English e-mail requests and it also confirms previous work by Hartford and Bardovi-Harlig (1996) and Chen (2001), who had the same findings.

Examples 1 and 2 below are provided as representative of NS and NNS e-mail requests gathered for this study.

Example 1: NS e-mail request

From Native Speaker ns@yahoo.com

To majetic.senka@yahoo.com

Subject From a student in your class

$\mathrm{Hi}$,

This is from Native Speaker, a student in your class. I am writing to you in regard to the paper due next Monday.

I would like to be given an extension until Wednesday if possible. On Sunday, I had to take my younger brother to the emergency room after he was injured playing football. We were at the hospital all day, and I wasn't able to finish my paper. I know your policy is not to grant extensions, but I was hoping you'd understand my circumstances. I couldn't foresee this emergency. I'd gladly supply you with supporting documentation. I understand you might not be able to do this, but if you could, I'd greatly appreciate it.

Thank you for your time.

Sincerely,

Native Speaker 
Example 2: NNS e-mail request

From Non Native Speaker nns@yahoo.com

To majetic.senka@yahoo.com

\section{Subject}

Dear Ms.,

I have a request on the homework assignment that you assigned to us which must due on Monday. One of my close relative has gotten into a car accident yesterday night and she's in a critical condition. I was the only close relative that she has in Bihać. Since I have to take care of her until she gets better, I have not enough time to do the assignment. Thus, could you extend the due date of that assignment, please? I have to apologize that I have such request; however, she really needs my help at this time. Please give me time to finish up.

Thank you very much!

Sincerely,

Your Student

Each of these examples was judged the same by two raters. Example 1 was rated "4-More Acceptable" for perlocution and "3- Polite" for politeness. Example 2 was rated "3-Acceptable" for perlocution and "4- Too Polite" for politeness. Although their ratings were similar, it is obvious that the pragmatic strategies employed in forming these two messages are quite different. To begin with, whereas the NS includes a subject in the subject field of the message, the NNS does not, which is a violation of netiquette guidelines. Secondly, whereas the NS proves identification, the NNS does not. This is also a violation of netiquette guidelines. Additionally, whereas the NS forms the request in a "preparatory - request statement - grounder" fashion, the NNS forms the request in a "preparatory - request statement - grounder - request question" fashion. This NS request pattern is the prototypical NS pattern found in the data set. Lastly, the NS message contains politeness and upgrader features discussed in the following section, whereas the NNS message does not. Altogether, these differences in pragmatic strategies contribute to the differences in ratings between the NS and NNS messages.

What are the differences between the pragmatic features of NS and NNS e-mail requests?

One of the most noticeable differences between the pragmatic features of NS and NNS e-mail requests has to do with the level of politeness. Table 2 below shows descriptive statistics of the e-mail politeness ratings. 


\begin{tabular}{lrrrrr}
\hline & N & M & SD & MIN & MAX \\
\hline NS & 29 & 3.07 & 0.65 & 2.00 & 4.00 \\
NNS & 45 & 3.42 & 0.78 & 2.00 & 5.00 \\
\hline
\end{tabular}

Table 2: Descriptive Statistics for Politeness

NSs were rated just average overall for politeness - not impolite and not too polite. However, across all of the NNS messages (pre-test, post-test, and delayed post-test), they were rated above average for politeness by nearly a half of a point. This may not seem like much of a difference, but it does show that NNSs tend to produce e-mail requests that may be interpreted as too polite, a feature which may affect the perlocution of the message. Specific pragmatic features employed by the NNSs and not by the NSs, which may affect politeness, include complements, expressions of gratitude, and repeated uses of politeness markers (e.g., "please"). This finding is consistent with the research by Chen (2001) discussed previously, who, as a result, concluded that NNS over-politeness in e-mail requests is due to cultural transfer. This point should be considered for future instructional designs of e-mail pragmatics materials and lessons.

Another interesting finding regarding the differences between the pragmatic features of NS and NNS e-mail requests had to do with the use of upgraders in the e-mail messages. Upgraders are negative pragmatic devices that serve to increase the impact of the request and, therefore, may reduce the perlocution of the message. Following Netiquette guidelines (Shea 1994; Hambridge 1995; Rinaldi 1998; Hughes 2002), the use of expletives, repetitions, exclamations points, time intensifiers, and all-capital letters should be avoided. Within the entire NS data set, not one upgrader is used. On the other hand, NNSs make use of orthographic upgraders (exclamation points and all-capital letters) 11 times, three of them in one message alone. Examples of orthographic upgraders used by NNSs are "EMERGENCY!" found in the subject heading of one message, "Hi!" found in the introductions of several messages, as well as "Thank you!" found in the closing of several more messages. Additionally, several NNSs use time intensifiers such as "ASAP", and the repetition-of-request strategy, which also serve as message upgraders.

What are the effects of instruction in the usage of appropriate pragmatic features when making e-mail requests?

By analyzing the NNS pre-, immediate-post, and delayed-post-test messages, it is evident that there were positive effects on instruction maintained over time. Regarding the perlocution of the e-mail requests, a one-way repeated-measures ANOVA was performed to test for significant treatment effect. The results of this analysis indicate that NNS messages increase in perlocution on the immediate-post-test, approaching "acceptable" on average. On the delayed-post-test, NNS messages maintain an increase in perlocution, although down from the immediate-post-test level and with no significance to the pre-test level. 


\begin{tabular}{lrrrr}
\hline Source & SS & $\boldsymbol{d f}$ & MS & $\boldsymbol{F}$ \\
\hline Between Tests & 2.311 & 2 & 1.156 & $3.753^{*}$ \\
\hline Within Tests & 12.933 & 42 & .308 & \\
\hline
\end{tabular}

Table 3: Results of One-Way Repeated-Measures ANOVA. Effect of International Treatment on Perlocution

This finding suggests the need for more instruction on pragmatic strategies to increase the perlocution of e-mail requests and maintain it over time. One suggestion for doing this is to include CMC pragmatics as competency in the academic writing curriculum and to provide a more comprehensive pragmatic analysis to include several different types of speech acts, such as apology and information exchange, in addition to requests. By doing so, instructional time for e-mail pragmatics would be extended throughout the semester, giving students many opportunities to practice writing strategies that are becoming more useful, and even necessary, in academic settings.

\section{CONCLUSION}

The study investigated the usage of pragmatics by NNSs of English when making e-mail requests. It contributes to the body of research in e-mail pragmatics by showing first that NSs and NNSs of English differ greatly in the pragmatic strategies that they use when making e-mail requests, and second that e-mail pragmatic features are teachable to NNSs. Findings from the study indicate that NNSs tend to produce messages that are rated as too polite, and at the same time judged to have low perlocutionary effect. Additional findings suggest that explicit instruction in e-mail pragmatics has a positive effect on the perlocution of e-mail messages, including the use of certain structure features and content pragmatic features.

This study is very limited in scope, containing a small number of participants, and examining only a few of the e-mail pragmatic features possible. However, it confirms in an instructional setting that e-mail pragmatics can and should consider ways to include the instruction of e-mail pragmatics in their curricula.

\section{REFERENCES}

Bardovi-Harlig, K. 2001. Evaluating the empirical evidence: Grounds for instruction in pragmatics? In K. Rose \& G. Kasper (eds.) Pragmatics in language teaching. Cambridge: CUP, 13-32.

Blum-Kulka, S., J. House \& G. Kasper (eds.). 1989. Cross-cultural pragmatics: Requests and apologies. Norwood, NJ: Ablex Publishing.

Brown, P. \& S. C. Levinson. 1987. Politeness: Some universals in language usage. Cambridge: CUP. 
Chen, C. F. E. 2001. Making e-mail requests to professors: Taiwanese vs. American students. Paper presented at the Annual Meeting of the American Association for Applied Linguistics. St. Louis, MO.

Essid, J. 2003. Basics of electronic writing. Writer's Web. [Internet]. Available at: http:// writing2.richmond.edu/writing/wweb/ewriting.html [20.11.2013].

Ford, S. 2003. "Dear, Mr Shawn": A lesson in e-mail pragmatics. TESOL Journal 12, 39-40.

Gains, J. 1999. Electronic mail: a new style of communication or just a new medium?: An investigation into the text features of e-mail. English for Specific Purposes 18 (1), 81-101.

Hacker, D. 2003. A Writer's Reference. Fifth edition. New York: St. Martin's.

Hall,J.K. 1999. The prosaics of interaction: The development of interactional competence in another language. In E. Hinkel (ed.) Culture in second language teaching and learning. Cambridge: CUP, 137-151.

Hambridge, S. 1995. RFC 1855: Netiquette Guidelines. [Internet]. Available at http://www. stanton.dtcc.edu/stanton/cs/rfc1855.htmll [20.11.2013].

Hartford, B. S. \& K. Bardovi-Harlig. 1996. "At your earliest convenience": A study of written student requests to faculty. In L. F. Bouton (ed.) Pragmatics and Language Learning Monograph Series, 7. Urbana, IL: University of Illinois at Urbana-Champaign.

House, J. 1996. Developing pragmatic fluency in English as a foreign language: Routines and metapragmatic awareness. SSLA 18, 225-252.

Hughes, S. W. 2002. E-mail etiquette. Online Writing Lab (OWL) at Purdue University. [Internet]. Available at: http://owl.english.purdue.edu/handouts/pw/p_e-mailett. html [20.11.2013].

Inglis, N. L. 1998. Worlds apart: Cross-cultural undercurrents in the use of e-mail and the Internet. Language International 10 (2), 16-17.

Kasange, L. A. 1998. Requests in English by second-language users. ITL, Review of Applied Linguistics, 123-153.

Kasper, G. 1992. Pragmatic transfer. Second Language Research 8 (3), 203-231.

Kasper, G. \& K. Rose. 2001. Pragmatics in language teaching. In K. Rose \& G. Kasper (eds.) Pragmatics in language teaching. Cambridge: CUP, 1-9.

Kasper, G. \& S. Blum-Kulka. 1993. Interlanguage pragmatics: An introduction. In G. Kasper \& S. Blum Kulka (eds.) Interlanguage Pragmatics. New York: OUP, 3-17.

Kim, I. 0. 2000. Relationship of onset age of ESL acquisition and extent of informal input to appropriateness and nativeness in performing four speech acts in English: A study of native Korean adult speakers of ESL. Ann Arbor, MI: UMI. Dissertation Abstracts International.

Kim, J. 1995. "Could you calm down more?": Requests and Korean ESL learners. Working Papers in Educational Linguistics 11(2), 67-82.

Kitao, K. 1990. A study of Japanese and American perceptions of politeness in requests. Doshisha Studies in English 50, 178-210.

Lan, L. 2000. E-mail: A challenge to standard English? English Today 16 (4), 23-29.

Li, D. 2000. The pragmatics of making requests in the L2 workplace: A case study of language socialization. The Canadian Modern Language Review 57 (1), 58-87.

Mach, T. \& S. Ridder. In Press. E-mail requests. Included in course packet for SLS 730: Seminar in Second Language Education, Professor Gabriele Kasper. 
Rinaldi, A. H. 1998. The Net: User Guidelines and Netiquette. [Internet]. Available at: http:// www.fau.edu/netiquette/net/ [20.11.2013].

Rose, K. R. 1994. Pragmatic consciousness-raising in an EFL context. In L. Bouton \& Y. Kachru (eds.) Pragmatics and Language Learning Monograph Series 5. Urbana, IL: University of Illinois at Urbana-Champaign, 52-63.

Rose, K. R. 1999. Teachers and students learning about requests in Hong Kong. In E. Hinkel (ed.) Culture in second language teaching and learning. Cambridge: CUP, 167180.

Rose, K. R. \& G. Kasper (eds.). 2001. Pragmatics in language teaching. Cambridge: CUP.

Schmidt, R. 1993. Consciousness, learning and interlanguage pragmatics. In G. Kasper \& S. Blum-Kulka (eds.) Interlanguage pragmatics. New York: 0UP, 21-42.

Schmidt, T. Y. 1994. Authenticity in ESL: A study of requests. Unpublished Master's Thesis, Southern Illinois University.

Shea, V. 1994. Netiquette. [Internet]. Available at: http://www.albion.com/netiquette/ book/index.html [20.11.2013].

St. John, E. \& D. Cash. 1995. German language learning via e-mail: A case study. ReCALL $7(2), 47-51$.

Suh, J. S. 1999. ESL Korean learners' decision-making processes in the performance of the speech act of requests. Paper presented at the Annual Meeting of the Teachers of English to Speakers of Other Languages. Seattle, WA.

Swales, J. M. \& C. B. Feak. 2000. English in today's research world: A writing guide. Ann Arbor, MI: University of Michigan Press.

Takahashi, S. 2001. The role of input enhancement in developing pragmatic competence. In K. Rose \& G. Kasper (eds.) Pragmatics in language teaching. Cambridge: CUP, 80102.

Tateyama, Y. 2001. Explicit and implicit teaching of pragmatic routines: Japanese sumimasen. In K. Rose \& G. Kasper (eds.) Pragmatics in language teaching. Cambridge: CUP, 200-222.

Trosborg, A. 1995. Interlanguage pragmatics: Requests, complaints, and apologies. Berlin: Mouton de Gruyter.

Warschauer, M. 1995. E-mail for English teaching. Alexandria, VA: TESOL.

Weasenforth, D. In Press. What do you think? Requesting responses from professors. Included in course packet for SLS 730: Seminar in Second Language Education, Professor Gabriele Kasper.

Weasenforth, D. \& S. Biesenbach-Lucas. 2000. "Please help me": L1/L2 variations in solicitations in electronic conferences. Paper presented at Second Language Research Forum. Madison, WI.

Yoshimi, D. R. 2001. Explicit instruction and JFL learner's use of interactional discourse markers. In K. Rose \& G. Kasper (eds.) Pragmatics in language teaching. Cambridge: CUP, 223-244. 


\section{SUMMARY}

\section{THE PRAGMALINGUISTIC AND SOCIOPRAGMATIC ASPECTS \\ OF ENGLISH: APPLYING ANALYTIC ABILITIES TO FOREIGN LANGUAGE TEACHING}

The current paper provides results of a study that investigated the usage of pragmatics by non-native speakers (NNSs) of English when making e-mail requests. Initial data from the study shows that NNSs differ from native speakers (NSs) in politeness and perlocution (i.e., the effect that an utterance has on its recipient) of their English e-mail requests. The data also show that NNSs and NSs differ in the specific pragmatic strategies related to the structure and content used in their e-mail requests. Additional data from this study indicates that explicit instruction can positively affect the perlocution of NNS e-mail requests and the long-term usage of pragmatic features found in the e-mail messages of NNSs, although the greatest effect is observed in the appropriate usage of structural features. The results of this study support the need for instruction of e-mail pragmatics to second language learners and reveal the possible benefits of such instruction.

KEYWORDS: e-mail requests, non-native speakers (NNSs), pragmatics, perlocution.

(Original scientific paper received 03.02.2013;

revised 05.09.2013;

accepted 01.10.2013) 